Table 2. Characteristic Properties of Lactic Oxidases

\begin{tabular}{|c|c|c|}
\hline & Iactic oxidase I & Lactic oxidase II \\
\hline Method of extraction & $\begin{array}{l}\text { Alternate freezing } \\
\text { and thawing }\end{array}$ & $\begin{array}{l}\text { Autolysis from ace- } \\
\text { tone powder }\end{array}$ \\
\hline $\begin{array}{l}\text { Heated at } 50^{\circ} \mathrm{C} . \\
\text { for } 10 \mathrm{~min} .\end{array}$ & Labile & Stable \\
\hline Dialysis & Stable & Labile \\
\hline $\begin{array}{l}\text { Precipitated with } \\
\text { acetic acid }\end{array}$ & Stable & Labile \\
\hline $\begin{array}{l}\text { With molecular } \\
\text { oxygen }\end{array}$ & Reacts directly & $\begin{array}{l}\text { Reacts in the pres- } \\
\text { ence of carrier }\end{array}$ \\
\hline $\begin{array}{l}\text { With methylene blue } \\
\text { or cytochrome } c\end{array}$ & Not affected & $\begin{array}{l}\text { Affected ; the enzyme } \\
\text { requires them as } \\
\text { carriers }\end{array}$ \\
\hline Prosthetic group or & $\begin{array}{c}\text { Flavine adenine } \\
\text { dinucleotide }\end{array}$ & $\begin{array}{l}\text { Diphosphopyridine } \\
\text { nucleotide }\end{array}$ \\
\hline Reaction product & Acetate & Pyruvate \\
\hline
\end{tabular}

tion is not inhibited by pyruvate. It appears, therefore, that this enzyme catalyses the oxidation of lactate to acetate and carbon dioxide with no intervention from pyruvate.

The addition of alcohol, azide, cyanide, hydrogen peroxide and active catalase prepared from beef liver, respectively, has no effect on the rate of reaction, and the addition of alcohol with strong liver catalase has no effect on the total amount of oxygen consumed and carbon dioxide produced. Consequently, we consider that the possibility of the formation of hydrogen peroxide is ruled out.

Lactic oxidase II. A larger amount of lactic oxidase II is contained in the acetone-powder extract than in the extract which is obtained by alternate freezing and thawing. Although we have not succeeded in purifying this enzyme, the activation by methylene blue, the cytochrome $c$ and cytochrome oxidase system, and diphosphopyridine nucleotide was demonstrated with the acetone-powder extract. In the presence of methylene blue, pyruvate was detected as the reaction product. The reaction catalysed will be perhaps as follows :

$\mathrm{CH}_{3} \mathrm{CHOH}-\mathrm{COOH}+\frac{1}{2} \mathrm{O}_{2} \rightarrow \mathrm{CH}_{3} \mathrm{COCOOH}+\mathrm{H}_{2} \mathrm{O}$.

The characteristic properties of the two distinct lactic oxidases are summarized in Table 2. As shown in the table, lactic oxidase $I$ is a new type of lactateoxidizing enzyme differing from the lactic dehydrogenases of animal tissues, yeast, $E$. coli, Gonococcus and higher plants. Lactic oxidase II is similar to the animal enzyme.

YUtChi YamamURA

Masamiti Kusunose

Emi Kusunose

Toneyama Institute of Tuberculosis,

Municipal Medical School, Osaka. Dec. 21.

\section{Growth of Rat Ovary in Tissue Culture}

THERE are few reports of rat tissue cultures producing growth comparable to that from other mammalian species or from chick explants. Martinovitch $^{1}$, working with rat pituitary and rat ovary in watch-glass cultures, was able to keep the tissues alive in vitro for a considerable length of time; but cell outgrowth was comparatively slight. Abercrombie and Harkness ${ }^{2}$ cultured regenerating rat liver. Fibroblasts or bile duct epithelium rarely grew from normal liver cultures, but appeared sporadically in cultures of regenerating material, the outgrowth varying with the state of liver regeneration. Only lymphocytes and granulocytes occurred in cultures regularly and in similar numbers regardless of the state of regeneration. The only case of rat pituitary tissue producing vigorous growth in vitro is that reported by Haymaker and Anderson ${ }^{3}$.

In the present experiments it has been found that extensive epithelial growth can be obtained in slide cultures of rat ovary if the explants are kept in a fluid medium for $24 \mathrm{hr}$. before being placed in the slide cultures.

As a result of preliminary cultures, it was decided that rats 27-31 days old and approximately $60 \mathrm{gm}$. in weight were the optimum age from which tissues should be taken. Histological sections showed that in such ovaries follicular tissue was at a maximum.

Whole ovaries were removed from the rats and washed in Simm's solution containing 10 per cent rat serum. From each ovary, the larger follicles were gently squeezed, and then from the remaining piece of ovary ten to fifteen explants $1-2 \mathrm{~mm}$. in diameter were cut. The expressed follicles, together with the larger ovarian explants, were transferred to an embryological watch-glass containing 2 c.c. of culture medium, which consisted of 50 per cent rat serum, 50 per cent rat embryo extract and streptomyein in the final concentration 0.0002 per cent. The watchglasses were covered with large coverslips, sealed and incubated for $24 \mathrm{hr}$. at $37^{\circ} \mathrm{C}$.

This 'preincubated' tissue was now cultured by the slide method. Explants were moored to the coverslip in a thin rat plasma-extract clot; a drop of fluid culture medium similar to that used for 'preincubation' was added and a meniscus drop culture finally prepared. Control cultures were prepared using fresh rat ovary in fresh medium. All cultures were incubated at $37^{\circ} \mathrm{C}$.

After 24-48 hr. incubation, on an average, 75 per cent of the cultures of 'preincubated' tissue showed growth; after a further $24 \mathrm{hr}$. epithelial sheets of cells were prominent. By renewing the fluid medium, cultures could be kept healthy for up to seven days, the final width of the growth varying from 2 to $4 \mathrm{~mm}$. On an average, 40 per cent of the control cultures grew and produced epithelium, but to a lesser extent than the experimental cultures.

The reasons for growth promotion and the beneficial properties of 'preincubation' are as yet undetermined. Rat tissue may be sensitive to injury, and injured cells fall from the explants, thus leaving healthy cells for culture. In transferring the explants to a fresh medium before culturing by the slide method, products of cell damage may be washed off. Slight separation of cells may occur during 'preincubation'. The effects of different culture media, and of duration and temperature of 'preincubation', require further study. The effect of 'preincubation' on the subsequent growth in vitro of other rat tissues should also be investigated since the optimum conditions for one tissue are not necessarily those required by other tissues.

This work was carried out during a short visit to the National Institute for Medical Research, London, and I wish to thank Sir Charles Harington and Dr. A. S. Parkes for making my visit possible. I am also indebted to Dr. A. U. Smith for many helpful suggestions, and for her stimulating interest in the work.

JEAN I. ScotT

Department of Surgery,

University of Aberdeen. Feb. 6.

${ }^{1}$ Martinovitch, P., Proc. Roy. Soc., B, 125, 232 (1938) ; 128, 138 (1939). Abercrombie, M., and Harkness, R. D., Proc. Roy. Soc., B, 138, 544 (1951).

3 Haymaker, W., and Anderson, F, J. Path. and Bact., 42, 399 (1936). 